\title{
Making Online Exams Through the Whatsapp Auto Application
}

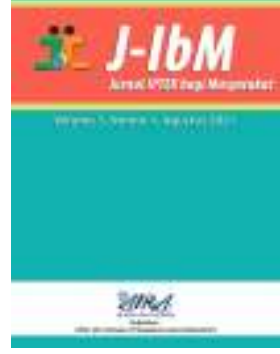

Pembuatan Ujian Online Melalui Aplikasi Whatsapp Auto

\author{
Cecep Maulana*, Suparmadi, Mohd. Siddik
}

Sekolah Tinggi Manajemen Ilmu Dan Komputer (STMIK) Royal; Kisaran; Indonesia;

*Correspondence: cecep.maulana1977@gmail.com

https:journal.aira.or.id/J-IbM |

Submission Received : 29-11-2021; Revised : 02-12-2021; Accepted : 06-12-2021; Published : 29-12-2021

\begin{abstract}
In the era of the Covid-19 pandemic, learning activities are only carried out using the internet, which forces teachers and students to communicate with each other through applications. The WhatsApp application is very familiar among children, adults, and even parents because the WhatsApp application is very easy to understand in its operation and is also very light to use on Android phones. This is very important to provide information for android users today, WhatsApp is one of the chat applications that are quite popular. Although there are many chat applications such as Telegram, Messenger, and others, WhatsApp is indeed a chat application that is easy to use and has various interesting features. In making online exams using WhatsApp, we do not use the features in WhatsApp, but we use a third-party application, namely WhatsApp Auto, which is connected to the WhatsApp application that we often use to chat every day, either in groups or privately. To get an effective online exam-making process, the teacher must download the WhatsApp auto application.
\end{abstract}

Keywords: Covid 19, Motorcycle Workshop, Appointment Information System

Abstrak: Di era padamik covid 19 membuat kegiatan pembelajaran hanya dilakukan dengan menggunakan internet yang memaksakan guru dan siswa saling berkomunikasi melalui aplikasi. Aplikasi whatsapp yang sangat familiar di kalangan anak-anak, dewasa bahkan orang tua karena aplikasi whatsapp sangat mudah di pahami dalam pengoprasinnya dan juga sangat ringan digunakan di hp android. Hal ini sangat penting untuk memberikan informasi bagi pengguna android sekarang ini, WhatsApp merupakan salah satu aplikasi chatting yang cukup populer. Meskipun terdapat banyak aplikasi chatting seperti telegram, Messenger dan lainnya, akan tetapi WhatsApp memang merupakan aplikasi chatting yang mudah digunakan serta mempunyai berbagai fitur yang menarik. Dalam pembuatan ujian online menggunakan whatsapp ini bukan menggunakan fitur yang ada di dalam whatsapp akan tetapi kita menggunakan aplikasi pihak ketiga yaitu whatsapp auto yang dimana aplikasi ini terhubung dengan aplikasi whatsapp yang sering kita gunakan untuk melakukan chatting sehari-hari baik dalam group ataupun pribadi. Untuk memperoleh proses pembuatan ujian online yang efektif, guru harus mendownload aplikasi whatsapp auto.

Kata Kunci: Covid 19, Bengkel Sepeda Motor, Sistem Informasi Appointment 


\section{Pendahuluan}

Seiring dengan perkembangan Teknologi Informasi (TI) yang pesat, serta kebutuhan akan media pembelajaran berbasis TI Sudah tidak dapat dipungkiri lagi bahwa kemajuan perkembangan komputer dan telekomunikasi telah merubah cara hidup masyarakat di dunia dalam menjalankan aktivitas sehari-hari. Keberadaan dan peranan teknologi informasi di segala sektor kehidupan tanpa sadar telah membawa dunia memasuki era baru globalisasi lebih cepat dari yang dibayangkan semula. Dampaknya tidak hanya berpengaruh pada sisi makro ekonomi dan politik masingmasing negara yang dipengaruhinya, tetapi lebih jauh telah merasuki aspek-aspek sosial budaya manusia termasuk bidang pendidikan (Edy Mulyana \& Asep Saepudin, 2006). Hal ini sangat memudahkan bagi penggunanya dalam menjalankan kegiatan terutama di dalam sekolah. Selama situasi padamik covid 19 kegiatan pembelajaran hanya dilakukan secara daring yang memungkinkan bagi penggunanya dalam bersosialisasi dengan penggunaan media di antara guru dan siswa. Media juga berfungsi untuk pembelajaran individual dimana kedudukan media sepenuhnya melayani kebutuhan belajar para siswa-siswi. Untuk mendukung dalam penggunaan media hal yang paling terpenting untuk memudahkan bagi siswa dan guru dalam masa padamik covid 19 adalah penggunaan smartphone sebagai media pembelajaran yang baik (Jauharil Maknuni, 2020).

Dengan penggunaan smartphone ini maka aplikasi serta fitur ikut mengalami peralihan yang tetap menjaga fungsi utama dari media tersebut sebagai sarana komunikasi. Banyak sekali kegunaan smartphone ini dalam membantu kita menyebarkan informasi baik untuk pribadi, pekerjaan ataupun untuk keluarga. Salah satu pembahasan yang menarik bagi peneliti untuk membahasnya adalah aplikasi whatsapp.

Whatsapp merupakan media sosial berbasis chat yang dapat digunakan untuk bertukar informasi antar pribadi maupun dalam grup. Dimana, aplikasi tersebut selain bisa berbagi informasi tetapi juga bisa mengirim gambar berupa foto-foto bahkan juga dapat merekam suara serta video. Sehingga hal ini merupakan kemudahan dan kelancaran dalam berkomunikasi (Sartika, 2018). Dalam beberapa tahun, pengguna Whatsapp semakin meningkat. Hal tersebut dibuktikan dengan hasil survei dari Statista tahun 2018 tentang pengguna aktif setiap bulan dari April 2013 sampai Desember 2017 (Statista, 2018).

Pengembangan media sosial whatsapp tidak hanya untuk alat bantu pembelajaran namun bisa dalam penyajian soal ujian (Taufik Barlian, Kiagus Ahmad Roni, Sofiah, Yosi Apriani, 2021) yang nantinya akan diterapkan di MTS Nurhasanah yang bertujuan untuk mempermudah guru dalam penyajian ujian berbasis online. Media sosial whatsapp sebagai media alat bantu pembelajaran diharapkan dapat membantu guru dalam pengerjaan untuk membuat soal ujian online dengan memberikan soal-soal melalui fitur yang ada di aplikasi whatsapp itu. Hal ini dibuktikannya pelakasanaan PKM di MTS Nurhsanah Batubara dalam penerapan membuat soal ujian selama masa covid 19 yang belum dilaksanakan tatap muka, hal ini mendorong tim PKM STMIK Royal untuk memberikan kontribusi dalam kegiatan ini. pemanfaatkan aplikasi ini tidak hanya digunakan sebagai interaksi media sosial tetapi juga membuat soal ujian yang memudahkan bagi siswa dalam penyampaian materi dalam pengerjaan tugas dan kuis. Setelah melihat dan menganalisis kondisi tersebut, maka tim pengabdian masyarakat Sekolah Tinggi Manajemen Ilmu Dan Komputer Royal Kisaran khususnya Program Studi Sistem Informasi melakukan pengabdian kepada masyarakat dengan dengan topik 
"Pembuatan Ujian Online Melalui Aplikasi WhatsApp Auto". Dengan menggunakan aplikasi ini akan memberikan solusi tepat dalam melaksanakan tugas-tugas berupa kuis dan latihan yang diberikan oleh guru dengan menggunakan smartphone yang memudahkan mereka dalam proses pembelajaran sehingga siswa bisa mengerjakan tugas dan quiz di aplikasi tersebut dengan baik.

\section{Metode}

Pelaksanaan kegiatan pengabdian kepada masyarakat harus berjalan dengan baik, maka perlu harus didukung oleh metode yang baik dalam kegiatan ini. Hal ini perlu peranan yang mendukung antara Tim Pengabdian Masyarakat STMIK Royal dengan pihak sekolah yakni MTS Nurhasanah.

Metode pelaksanaan dalam pengabdian masyarakat ini adalah dengan cara melaksanakan kegiatan melalui diskusi dan pelatihan dalam bentuk presentasi, dengan menjelaskan dasar teori dan praktek langsung(Dortiana Marpaung, 2018). Hal ini dibuktikan dengan mengadakan sosialisasi kepada guru-guru tentang aplikasi whatsapp yang sering digunakan dalam melakukan sosial media namun bisa digunakan sebagai Elearning untuk pembuatan ujian online yang nantinya diberikan kepada siswa yang bisa melakukan kegiatan pembelajaran dan pengerjaan ujian tersebut pada aplikasi whatsapp tersebut. Melalui aplikasi ini bagi guru-guru MTS Nurhasanah sadar dalam penerapan android bukan saja sebagai sumber bersosialisasi tetapi juga sumber informasi dalam pembuatan ujian online.

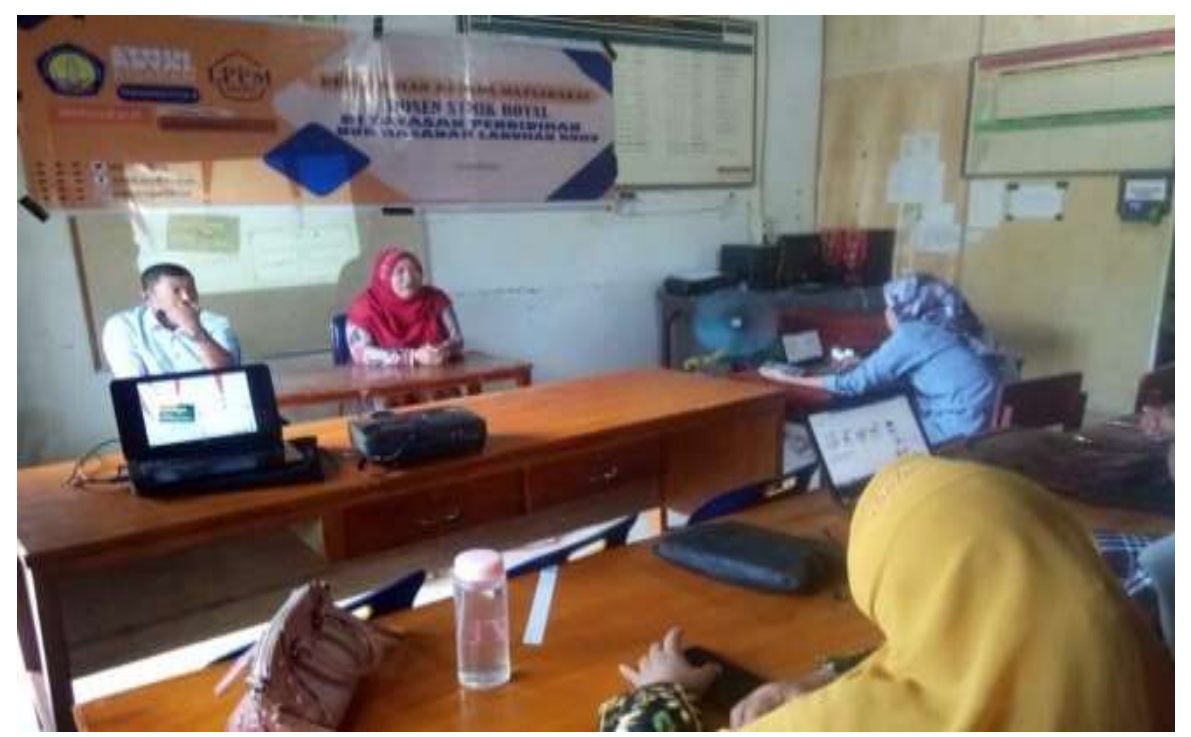

Gambar 1. Sosialisasi Penerapan WhatsApp Auto untuk Ujian Online

Selama kegiatan, pemateri menyampaikan tentang whatsapp auto sebagai user friendly dalam pengadaan aplikasi yang didukung oleh Email, google drive, google sheet serta excel (Aisyah Karmila, 2020) pengadaan teks dan kolom sebagai bentuk soal dan jadwal kegiatan yang yang ada di menu tersebut. Diharapkan nantinya guru-guru bisa implementasikan aplikasi ini dalam pengembangn teknologi informasi untuk dijadikan sumber pengetahuan dan alternatif untuk melakukan pembelajaran jarak jauh di masa pandemi covid 19 khususnya bagi guru-guru MTS Nurhasanah Labuhan Ruku Kec. Talawi Kab. Batu-bara. Media pembelajaran jarak jauh sangat dibutuhkan pada masa pandemi Covid-19 saat ini. Keterbatasan Interaksi guru dengan siswa yang 
mengharuskan merubah pola pembelajaran tatap muka menjadi daring (dalam jaringan) online, menjadi salah satu hambatan proses belajar mengajar di sekolah (Cecep Maulana, Ricki Ananda, William Ramdhan, Dahriansah, 2021).

Dengan kata lain, melalui Media sosial dengan aplikasi whatsapp auto dalam pembuatan ujian online guru-guru akan terbantu dalam pengerjaan membuat ujian online kepada siswa-siswinya dengan cepat dan tepat dalam pengadaan peranan teknologi yang nantinya akan diimplementasikan bagi guru-guru di MTS Nurhasanah sebagai peranan penting penggunaan teknologi informasi yang kedepannya dijadikan sumber pengetahuan dari media tersebut akan di jelajah dalam pembelajaran dengan menggunakan media elektronik atau disebut juga sebagai E-learning (Setyoningsih, 2015).

Bagi guru diminta untuk mendownload di playstore whatsapp auto yang memiliki beberapa aplikasi pendukung seperti akan tampilan gambar dibawah ini

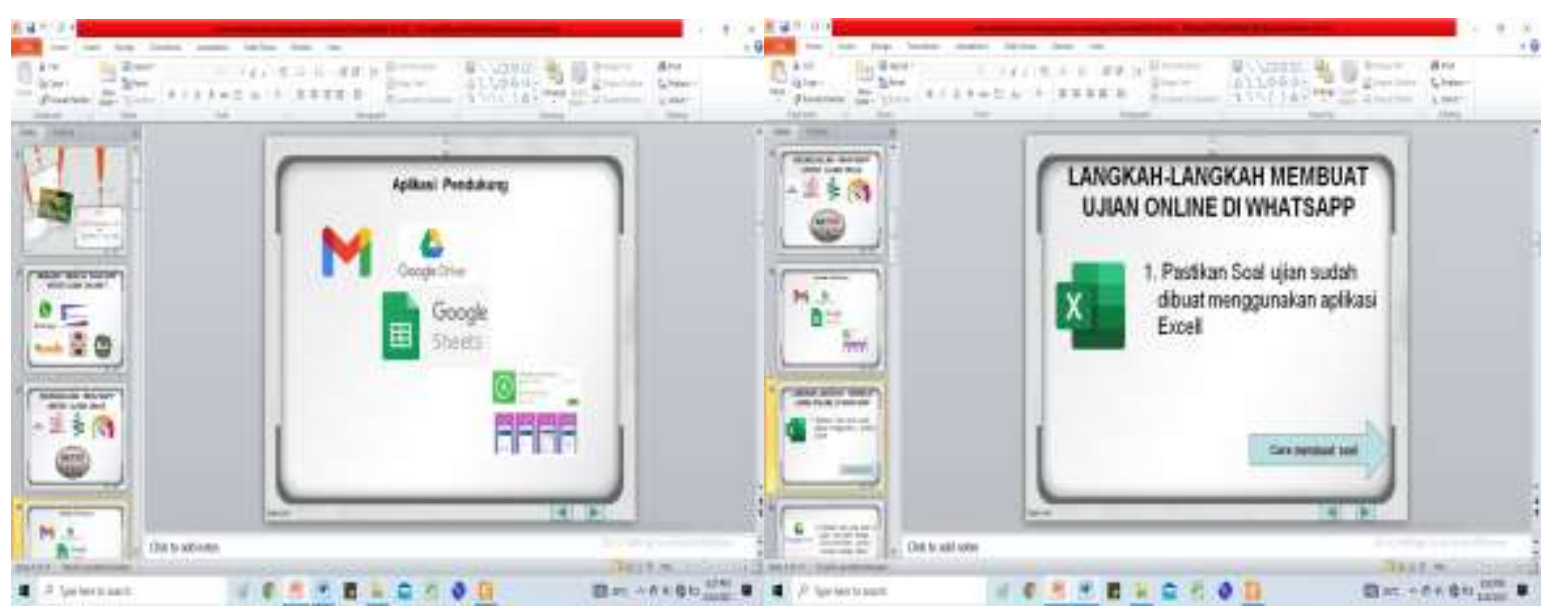

Gambar 2. Whatsapp Auto Memiliki Pendukung untuk Ujian Online

Metode yang terdapat dalam kegiatan pengabdian Masyarakat dengan pembuatan ujian online melalui aplikasi Whatsapp Auto. Di MTS Nurhasanah Labuhan Ruku. Kec. Talawi Kab. Batu-bara.

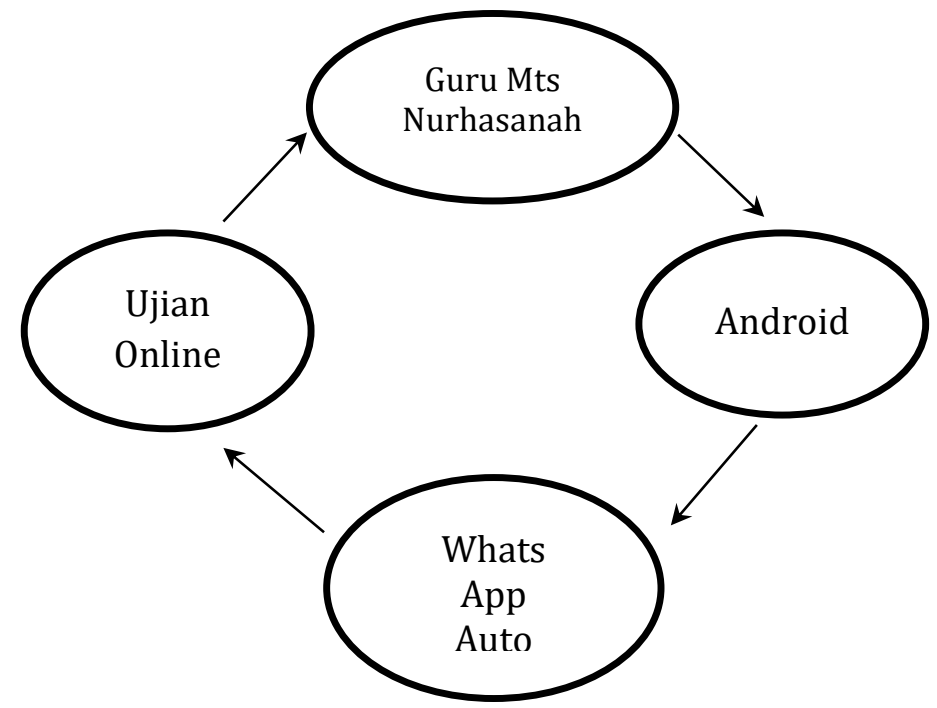

Gambar 3. Metode Pelaksanaan Pengabdian Kepada Masyarakat 


\section{Hasil}

Berdasarkan wawancara, tanya jawab dan pengamatan langsung selama kegiatan berlangsung, kegiatan pengabdian pada masyarakat ini memberikan hasil sebagai berikut

1. Meningkatnya pengetahuan dalam perkembangan teknologi informasi dari aplikasi whatsapp auto sebagai pembuatan ujian online di MTS Nurhasanah labuhan ruku kec. Talawi kab. Batu-bara.

2. Meningkatnya keterampilan bagi guru-guru MTS Nurhasanah labuhan ruku kec. Talawi kab. Batu-bara dalam menggunakan aplikasi whatapp auto untuk pembuatan ujian online selama masa padamik covid 19.

Sebagai hasil kegiatan PKM ini maka kita bisa melihat table 1 dimana menunjukan nilai hasil peran serta guru-guru MTS Nur Hasanah dalam kegiatan Pengabdian Masyarakat ini.

Table.1 Hasil Pencapaian Pembuatan Ujian Online Melalui Aplikasi Whatsapp Auto Bagi Guru-guru MTS Nurhasanah Labuhan Ruku. Kec. Talawi Kab. Batu-bara

\begin{tabular}{|c|l|c|}
\hline No & \multicolumn{1}{|c|}{ Uraian } & Skor Akhir \\
\hline 1 & Penguasaan memahami petunjuk Kegiatan & 9,0 \\
\hline 2 & $\begin{array}{l}\text { Minat menjalankan Aplikasi Whatsapp Auto } \\
\text { dalam pembuatan ujian online }\end{array}$ & 85 \\
\hline 3 & $\begin{array}{l}\text { Kemampuan penggunaan aplikasi Whatsapp } \\
\text { Auto dalam pembuatan ujian online }\end{array}$ & 90 \\
\hline 4 & Tingkat akurasi & 85 \\
\hline $\begin{array}{l}\text { Keterangan: } \\
\text { Guru -guru memiliki nilai 90 menunjukan } \\
\text { penguasaan sangat baik } \\
\text { Guru-guru memiliki nilai 85 menunjukan } \\
\text { penguasaan baik }\end{array}$ & \\
\hline
\end{tabular}

\section{Diskusi}

Untuk pencapaian secara maksimal dan berjalan dengan baik, maka perlu dilakukan diskusi tentang hasil pengabdian masyarakat, hal ini berhubungan dengan pemahaman yang lebih terutama pada diskusi teoritik yang begitu relevan dengan temuan hasil pengabdian masyarakat. Juga mendiskusikan tentang temuan teoritis dari proses pengabdian mulai awal sampai terjadinya perubahan yang nyata.

pembahasan hasil pengabdian masyarakat ini dikuatkan dengan referensi dan perspektif teoretik yang didukung dengan literature review yang relevan Kegiatan pengabdian masyarakat dilaksanakan di sekolah MTS Nurhasanah labuhan Ruku Kec. Talawi Kab. Batu-bara dimana pembuatan ujian online melalui aplikasi whatsapp auto ini sangat membantu guru dalam penerapan ini kepada siswa sebagai perkembangan elearning dan solusi yang tepat selama masa padamik Covid 19 khususnya memberikan 
tugas, quiz dan ujian berbasis online melalui whatsapp auto meliputi: Agenda awal yang dilaksanakan berupa rapat program kerja. Rapat dengan kepala sekolah dan guru-guru seluruh bidang studi Kegiatan selanjutnya adalah koordinasi dan diskusi yang berhubungan dengan jadwal kegiatan yang tepat dalam menentukan terkait program pengabdian masyarakat yang berhubungan dengan perkembangan e-learning dengan menggunakan android sebagai sistem operasi yang umum digunakan pada perangkat mobile seperti handphone dan tablet, kemudian mendownload whatsapp auto untuk membuat ujian online(Amin, 2020).

Hal ini tertuju pada langkah-langkah dan cara membuat soal ujian online melalui whatsapp auto dapat dilihat dibawah ini:

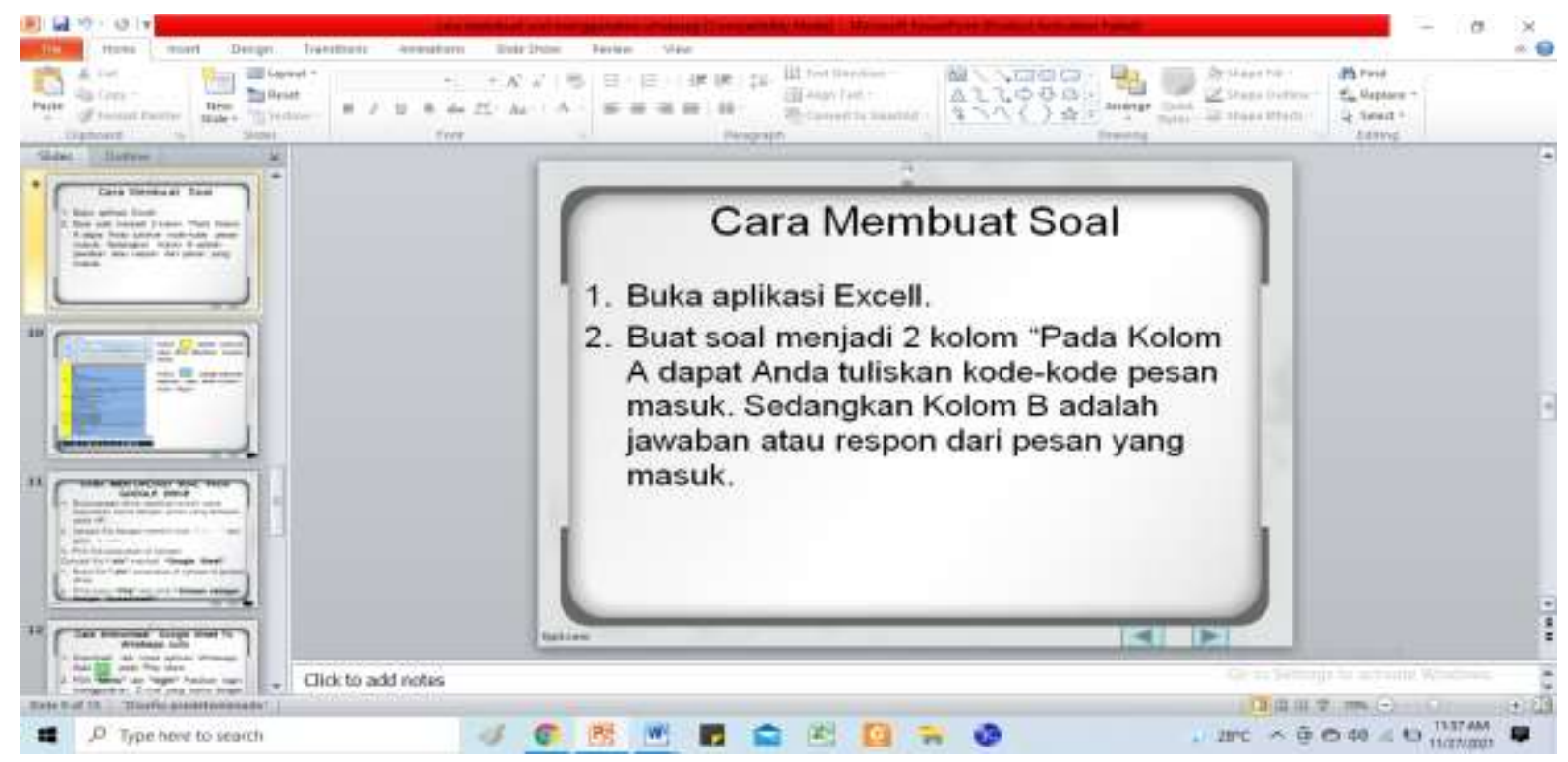

Gambar 4. Cara Membuat Soal Melalui Whatsapp Auto

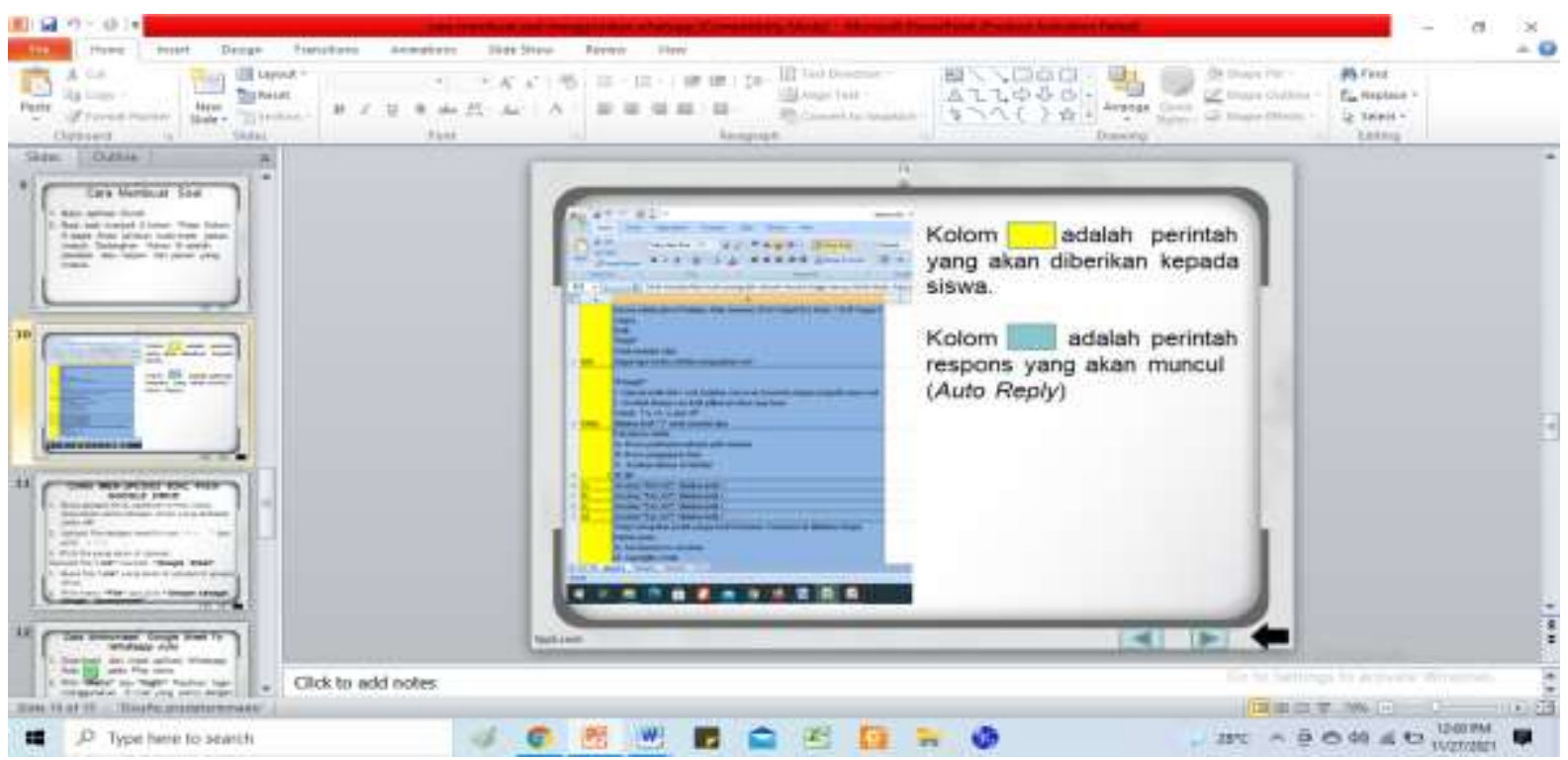

Gambar 5. Cara Menentukan Kolom Soal Ujian Online Melalui Whatsapp Auto 


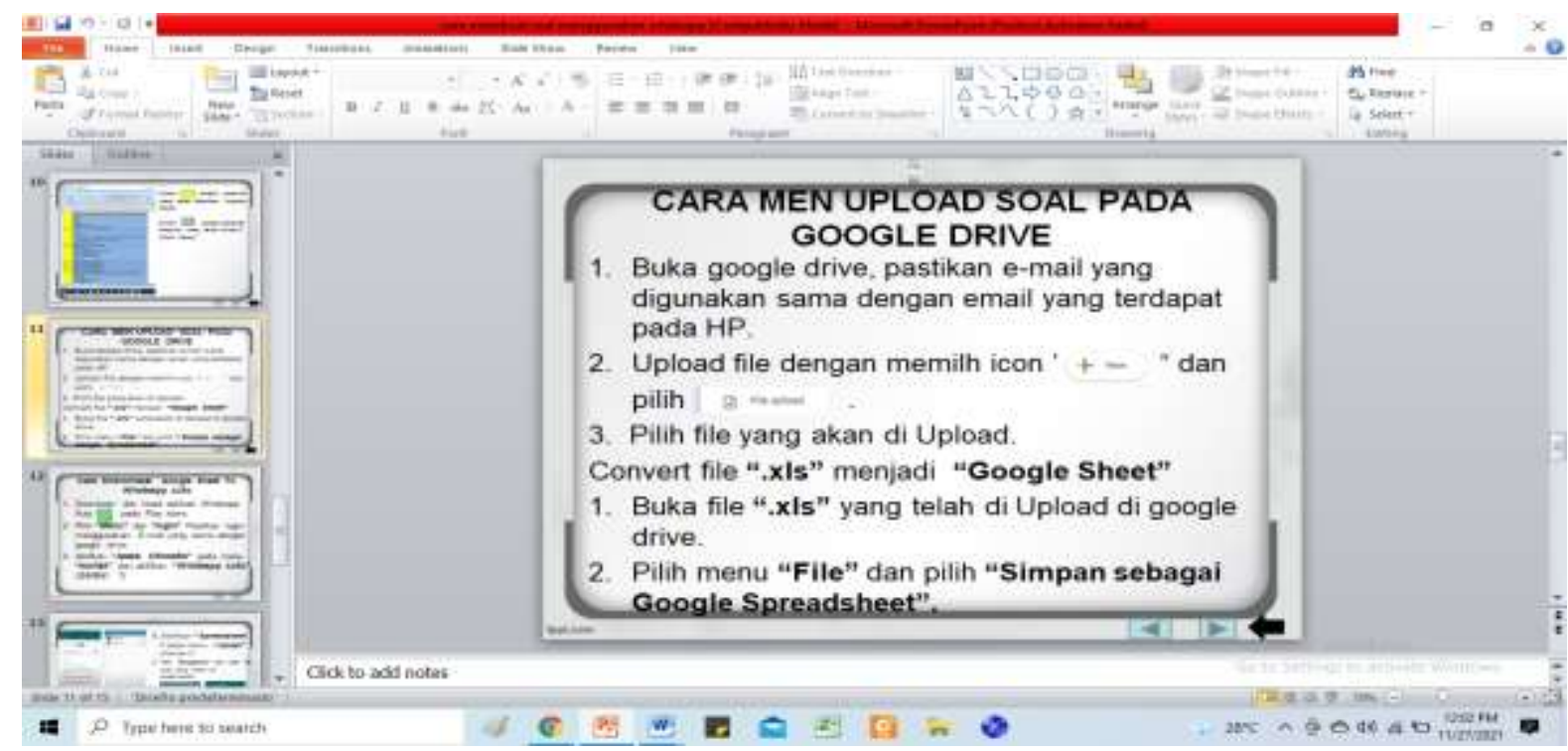

Gambar 6. Cara Mengupload Soal Ujian Online Melalui Google Drive

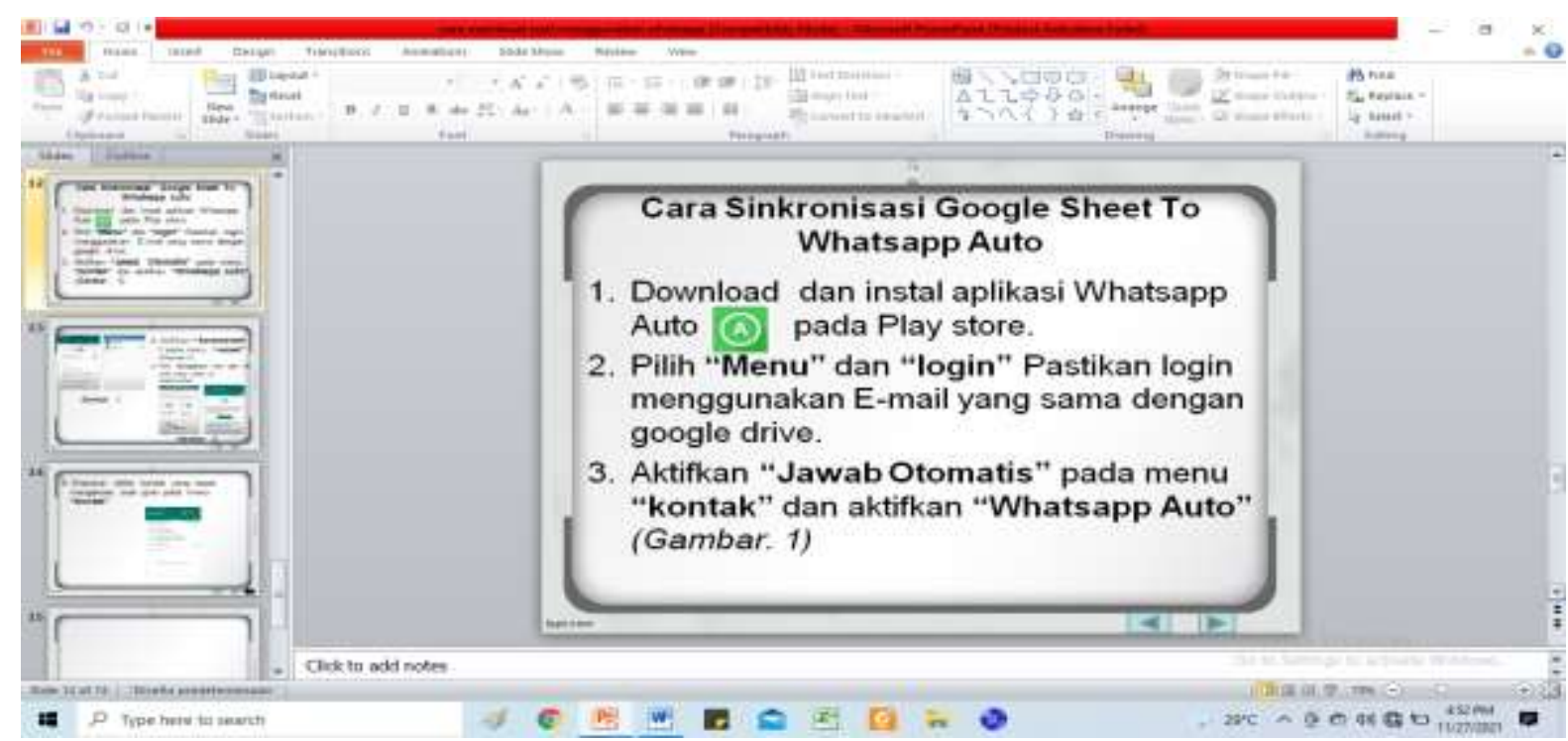

Gambar 7. Cara Sinkronisasi Google Sheet to Whatsapp Auto 


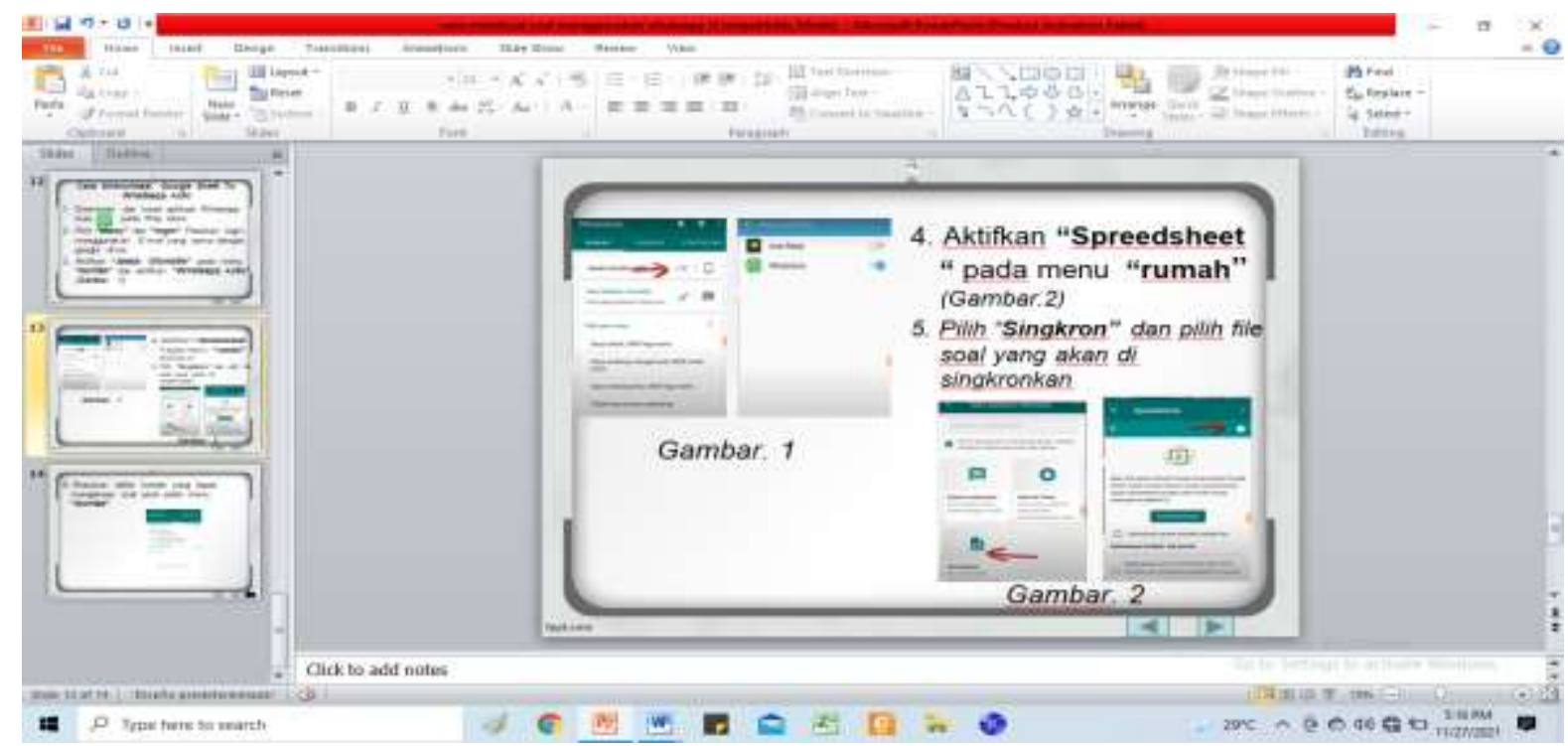

Gambar 8. Cara Aktifkan Spreadsheet pada Menu Home

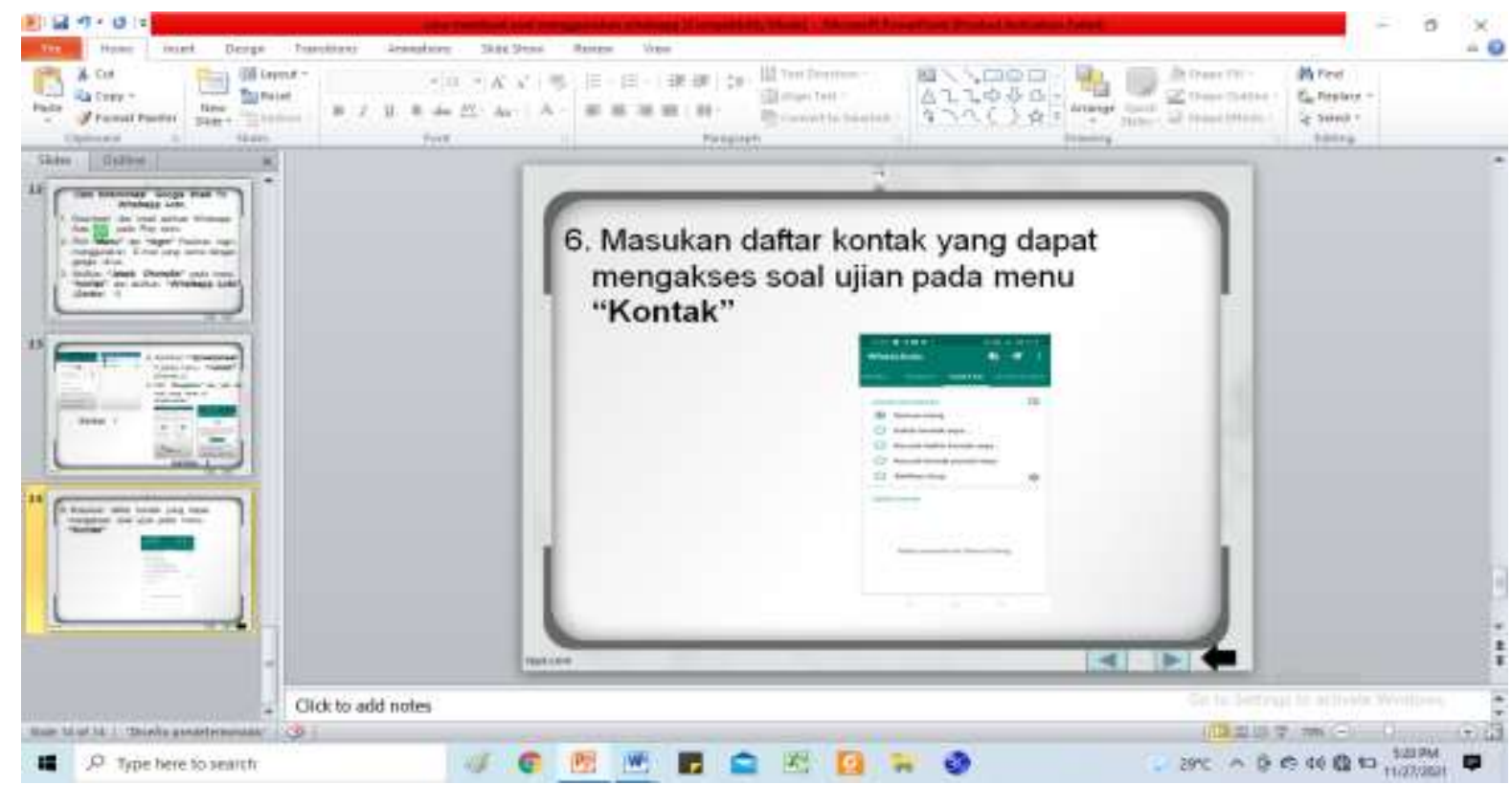

Gambar 9. Cara Masukan Daftar Kontak untuk Mengakses Ujian pada Menu Kontak

\section{Kesimpulan}

Beberapa faktor yang mendukung terlaksananya kegiatan pengabdian kepada masyarakat ini adalah pihak MTS Nurhasanah Labuhan Ruku Kec. Talawi Kab. Batu-bara dalam pembuatan ujian online yang telah mendukung terlaksananya kegiatan PKM ini dengan baik, serta besarnya minat dan kemauan peserta dalam pelaksanaan pkm ini, sehingga kegiatan berlangsung dengan lancar dan efektif. Sedangkan faktor penghambatnya adalah keterbatasan waktu pelatihan. dengan aplikasi WhatsApp Auto guru MTS Nurhasanah labuhan ruku kec. Talawi kab. Batu-bara akan lebih mudah untuk menilai karena dengan WhatsApp Auto dapat dijangkau oleh semua siswa. Dari keunggulan - keunggulan tersebut maka pembelajaran akan lebih mudah dan terarah. 
Setelah adanya aplikasi WhatsApp Auto peserta didik bersemangat dan termotivasi untuk selalu belajar dan membaca materi, menggali pengetahuan yang ada pada buku,. Dengan adanya aplikasi WhatsApp Auto guru lebih praktis dalam menyampaikan ujian online kepada peserta didik selama masa covid 19 dan sangat bersosialisasi dalam kegiatan pengerjaan soal. Guru menjadikan suasana belajar lebih fleksibel dengan memberi dispensasi kepada siswa yang belum bisa mengerjakan karena kondisi jaringan yang tidak stabil misalnya, guru juga memfasilitasi kesulitan yang dialami siswa dengan memberikan tutorialnya melalui hasil screen recording tentang cara melaksanakan ujian yang dibagikan ke grup. Hal ini dilakukan agar siswa dapat mengerjakan soal dengan langkah yang benar. Seusai pembelajaran, guru meminta siswa memberikan kesan atas pembelajaran yang telah dilakukan, dan banyak komentar positif dari siswa tersebut. Sebagian besar siswa merasa tertantang menerima paket soal dengan cara pemberian dan tampilan yang berbeda, dimana siswa langsung mendapat respons otomatis apakah jawabannya benar atau salah. Hal ini memicu semangat dan menumbuhkan keinginan siswa untuk mengurangi rasa penasaran mereka dengan mengerjakan soal lebih berhatihati. Siswa juga senang menerima jumlah nilai secara langsung, sehingga guru tidak perlu lagi mengoreksi hasil jawaban.

\section{Pengakuan}

Ucapan terima kasih kami kepada seluruh rekan-rekan yang turut berpartisipasi dalam kegiatan ini, kepada ketua pemipinan STMIK Royal Kisaran yang telah memberikan motivasi kuat dalam kegiatan ini juga tidak lupa juga kami mengucapkan terima kasih kepada ketua LPPM STMIK Royal atas kontribusinya serta bantuan sehingga kegiatan ini dapat berjalan dengan lancar, ucapan terima kasih yang setinggi-tingginya kepada pimpinan MTS Nurhasanah yang telah memberikan kepercayaan yang penuh dalam melaksanakan kegiatan Pengabdian Masyarakat berlangsung lancar dan tetap menerapkan protokol kesehatan selama masa padamik covid 19. Demikian pula ucapan terima kasih disampaikan Kepala Sekolah MTS Nur Hasanah yang telah memberi ruang dan waktu untuk melaksanakan kegiatan ini sampai akhir kegiatan.

\section{Daftar Pustaka}

Karmila, A. (2020). Pemanfaatan Google Drive Berbasis Cloud Computing Sebagai Media Penyimpanan oleh Pustakawan di Perpustakaan Universitas Islam Negeri Sumatera Utara. Diambil dari: https://repositori.usu.ac.id/handle/123456789/28947

Amin (2020). Cara Membuat Soal Ujian Online di WhatsApp Auto Response. Diambil dari: https://muh-amin.com/cara-membuat-soal-ujian-online-di-whatsapp-auto response.

Maulana, C., Ananda, R., Ramdhan, W., \& Dahriansah, D. (2021). Pemanfaatan E-Learning Pada Penggunaan Aplikasi Edmodo Di Smk Negeri 1 Setia Janji. Jurdimas (Jurnal Pengabdian Kepada Masyarakat) Royal, 4(2), 203-210.

Mulyana, E., \& Saepudin, A. (2019). Perkembangan Dan Pemanfaatan Teknologi Informasi Dalam Penyelenggaraan Pendidikan Jarak Jauh. Jurnal Teknodik, 119-134.

Marpaung, D. (2018). Penerapan Metode Diskusi Dan Presentasi Untuk Meningkatkan Minat Dan Hasil Belajar Siswa Di Kelas Xi Ips-1 Sma Negeri 1 Bagan 
Sinembah. School Education Journal Pgsd Fip Unimed, 8(4), 360-368.

Maknuni, J. (2020). Pengaruh Media Belajar Smartphone Terhadap Belajar Siswa Di Era Pandemi Covid-19 (The Influence of Smartphone Learning Media on Student Learning in The Era Pandemi Covid-19). Indonesian Education Administration and Leadership Journal (IDEAL), 02 (02), 94-106.

Sartika, (2018) Kegunaan Whatsapp Sebagai Pembelajaran pada Mahasiswa Ilmu Komunikasi STISIP Persada Bunda. Medium Jurnal Ilmiah Fakultas Ilmu Komunikasi Universitas Islam Riau,6 (2).

Setyoningsih, S. (2015). E Learning: Pembelajaran Interaktif Berbasis Teknologi Informasi. ELEMENTARY: Islamic Teacher Journal, 3(1).

Statista (2018). Number of monthly active WhatsApp users worldwide from April 2013 to December 2017 (in millions). Diambil dari: https://www.statista.com/statistics/260819/number-of-monthly-activewhatsappusers. Diakses selasa, 13 Februari 2018.

Barlian, T., Roni, K. A., Sofiah, S., \& Apriani, Y. (2021). APLIKASI WHATSAPP SEBAGAI MEDIA ALTERNATIF UJIAN ONLINE DI SIT MUSH'AB BIN UMAIR. Martabe: Jurnal Pengabdian Kepada Masyarakat, 4(1), 268-273. 